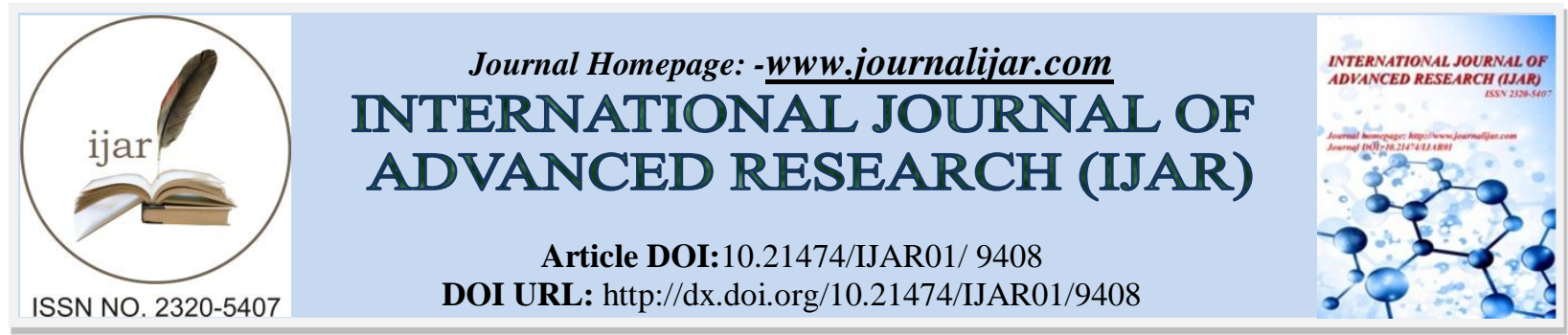

RESEARCH ARTICLE

\title{
A COMPARATIVE STUDY OF HOMOCYSTEINE LEVEL IN THYROID DYSFUNCTIONS BEFORE OR DURING TREATMENT.
}

\section{Dr. Kamlesh Tanwani.}

\section{Manuscript Info}

\section{Manuscript History}

Received: 20 May 2019

Final Accepted: 22 June 2019

Published: July 2019

Key words:-

Hypothyroid, Homocysteine, RIA,

\begin{abstract}
Introduction: Hyperhomocysteinemiais a disease involving abnormal homocysteine metabolism and is characterized by increased level of total homocysteine concentration (normal $5-15 \mu \mathrm{mol} / \mathrm{L}$ ). Many factors like dietary folate, cynocobalamine deficiency or thyroid disorders are the most common causes for increased homocysteine level. Thus this present study was planned to delineate the usefulness of levothyroxin to evaluate changes in homocysteine level in hypothyroid patients.

Material And Method: The present study was conducted on 75 patients of hypothyroidism of either sex in Department of Biochemistry, J.L.N. Medical College \& Hospital, Ajmer. Serum homocysteine level was measured by ELISA while thyroid function tests were evaluated by RIA method.

Result And Discussion: Before treatment serum homocysteine level was higher in hypothyroid patients $(17.10 \pm 3.09 \mu \mathrm{mol} / \mathrm{L})$ as compared to normal subjects $(8.15 \pm \mathrm{n} 0.345 \mu \mathrm{mol} / \mathrm{l})$. During treatment a significant decrease was observed in hypothyroid patients $(10.81 \pm 1.96 \mu \mathrm{mol} / \mathrm{L})$

Conclusion: It is concluded thatsupplementation of thyroxin in hypothyroid patients can cause significant decrease in level of homocysteine which can further decrease risk of coronary artery disorders in these patients .
\end{abstract}

Copy Right, IJAR, 2019,. All rights reserved.

\section{Introduction:-}

Thyroid disorders are the most common endocrine abnormalities encountered in clinical practices. Insufficient thyroid hormone secretion results in hypothyroidism. The activity of MTHFR gene (gene involve in homocysteine metabolism) reduces in underactive thyroid and further leads to hyperhomocysteinemia in these patients.

\section{Aims \& objectives:-}

To evaluate serum homocysteine levels in hypothyroid patients before treatment and during treatment (thyroxin).

\section{Material \& Methods:-}

The present study conducted on 75 clinically proven hypothyroid patients of both sex in the Department of Biochemistry, J.L.N. Medical College, Ajmer. The selected patients were then informed about the procedure and written informed consent was taken. The results were compared with age matched 75 healthy control subjects of either sex. Following investigation were performed in all the subjects included in this study:

1. Serum T3, Serum T4 and Serum TSH by RIA technique. 
2. Serum homocysteine by ELISA technique

Table 1:-Mean Serum homocysteine level of the subjects studied

\begin{tabular}{|c|c|c|}
\hline S.No & Group studied & $\begin{array}{c}\text { Serum Homocysteine } \\
\text { (Mean } \pm \text { S.D.) }\end{array}$ \\
\hline 1 & Healthy Controls & $8.15 \pm 0.345$ \\
\hline 2 & Hypothyroid Patients (Before treatment) & $17.10 \pm 3.09$ \\
\hline 3 & Hyperthyroid Patients (During treatment) & $10.81 \pm 1.96$ \\
\hline
\end{tabular}

Table 2:-Statistical analysis of Serum homocysteine among the groups studied

\begin{tabular}{|c|l|c|}
\hline & \multicolumn{1}{|c|}{ Group Compared } & p-value \\
\hline 1 & Healthy controls v/s Hypothyroids (before treatment) & $0.0001(\mathrm{HS})$ \\
\hline 2 & Healthy controls v/s Hypothyroids (during treatment) & $>0.0061(\mathrm{NS})$ \\
\hline
\end{tabular}

\section{Results:-}

75 patients suffering from hypothyroidism ( 24 males and 51 females) and 75 healthy control subjects ( 24 males and 51 females) were studied for thyroid function tests and serum homocysteine level.

The mean values for serum homocysteine level was $8.15 \pm 0.345 \mu \mathrm{mol} / \mathrm{L}$ for healthy control subjects. For hypothyroid patients, homocysteine levels were $17.10 \pm 3.09 \mu \mathrm{mol} / \mathrm{L}$ and $10.81 \pm 1.96 \mu \mathrm{mol} / \mathrm{L}$ before treatment and during treatment respectively.

\section{Discussion \& conclusion:-}

A highly significant relationship was observed in serum homocysteine levels when hypothyroid subjects $(\mathrm{p}=$ 0.0001) were compared with the healthy controls before treatment. Further these patients showed a non significant (p>0.0061) relationship when compared with the healthy control subjects during treatment.

Before treatment, serum homocysteine level were higher in patients with hypothyroidism while during treatment a decrease was observed in serum homocysteine level in these patients

Hypothyroidism decreases hepatic levels of enzymes involved in the remethylation pathway of homocysteine resulting in hyperhomocysteinemia. Supplementation of thyroxin to patients of hypothyroidism cause significant decrease level of serum homocysteine in these patients. 